\title{
Diel patterns of cell division and growth rates of Synechococcus spp. in Long Island Sound*
}

\author{
Edward J. Carpenter ${ }^{1}$, Lisa Campbell ${ }^{2}$ \\ ${ }^{1}$ Marine Sciences Research Center, State University of New York, Stony Brook, New York 11794, USA \\ ${ }^{2}$ Hawaii Institute of Geophysics, University of Hawaii, Honolulu, Hawaii 96822, USA
}

\begin{abstract}
Synechococcus spp. in Long Island Sound, USA, had distinct diel patterns of cell division throughout most of the year. Based on cell division patterns, it appears that Synechococcus spp. populations different from those of the Sargasso Sea were typical in Long Island Sound waters. The magnitude of the peak in the diel pattern of cell division was a good indicator of actively growing populations. From frequency of dividing cell data, growth rates were estimated. Maximal growth rate (1.56 divisions $\mathrm{d}^{-1}$ ) was observed at the end of May (at $16^{\circ} \mathrm{C}$ ) when we noted the most rapid increase in cell number. Greatest rate of production was during August (mean $59 \mathrm{mg} \mathrm{C} \mathrm{m}^{-2} \mathrm{~d}^{-1}$ ) when cell density was greatest. In winter, a definite diel pattern was lacking, so accurate growth rates could not be calculated at this time. Annual rate of production by Synechococcus spp. was calculated to be $4 \mathrm{~g} \mathrm{C} \mathrm{m}^{-2}$, and this is ca $2 \%$ of the total rate of production by phytoplankton in Long Island Sound.
\end{abstract}

\section{INTRODUCTION}

Picoplankton contribute a sizeable percentage of the primary production in the open ocean (Bienfang \& Takahashi 1983, Li et al. 1983, Glover et al. 1986. Waterbury et al. 1986). Because the chroococcoid cyanobacteria Synechococcus spp. are the major group within this size range, much interest has been shown in determining their growth rates. Investigators of oceanic picoplankton have relied largely upon size fractionation to determine rate processes for different size classes. In studies of productivity, the 0.6 to $1.0 \mu \mathrm{m}$ fraction has been found to provide a relatively pure sample ( $\geq 90 \%$ of the total) of Synechococcus spp. cells (Glover et al. 1986). However, errors in estimates of Synechococcus spp. productivity or growth rates can result if the fractionated sample is not sufficiently pure. For example, a $<1 \mu \mathrm{m}$ fraction may contain small eukaryotes which contribute a proportionately larger amount to the productivity measurement (Murphy \& Haugen 1985). Other possibilities for error include the required sample processing and/or confinement during incubations, which have been discussed previously (Campbell \& Carpenter 1986).

We have proposed the frequency of dividing cells (FDC) technique to determine growth rates of

\footnotetext{
- Marine Sciences Research Center Contribution No. 613
}

Synechococcus spp. populations. This method avoids potential artifacts associated with bottle incubation, and it permits estimation of a specific growth rate for an individual group, rather than for all organisms in a given fraction (Campbell \& Carpenter 1986). We previously observed seasonal patterns of populations of Synechococcus spp. in coastal Long Island waters (Campbell \& Carpenter 1987). Because of their abundance, we were interested in determining how their growth rates varied, as well as estimating their contribution to primary production. Synechococcus spp. populations make a smaller contribution to primary productivity in coastal (typically 5 to $10 \%$ ) than in oceanic regions (Glover et al. 1986, Waterbury et al. 1986). Results reported here are observations on the diel patterns of cell division of Synechococcus spp. in natural populations in Long Island Sound. Using the observed frequency of dividing cells, we estimated growth rates and calculated their potential contribution to primary production.

\section{MATERIALS AND METHODS}

Collections were made at Crane Neck Beach on the north shore of Long Island, New York, USA (Fig. 1) at approximately monthly intervals. Using a plastic bucket, samples were collected by wading out from the 


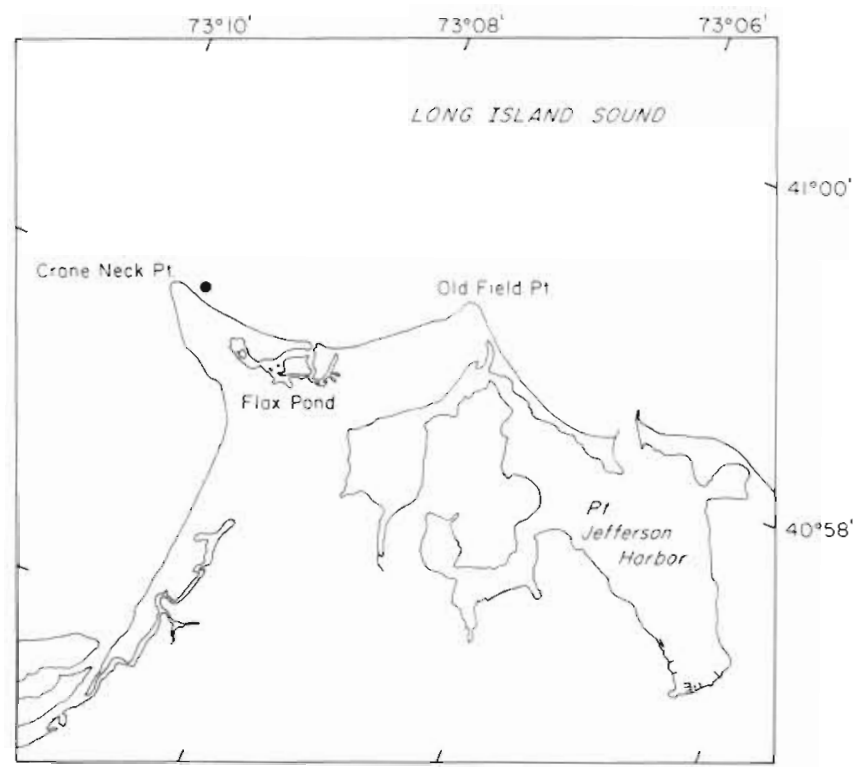

Fig. 1. Study site, Crane Neck, on north shore of Long Island, New York, USA

beach to water $1 \mathrm{~m}$ deep. The sample site typically had low turbidity and a salinity between 25 and $28 \%$. Tidal amplitude at Crane Neck is $2 \mathrm{~m}$, and the site experiences high tidal mixing

On each sampling date, seawater samples were collected, and temperature and salinity were recorded hourly beginning at 06:00 h. After several $24 \mathrm{~h}$ profiles were observed, and the time of maximum in percentage of dividing cells was known, we limited our sampling to daylight hours. This was because cell division in our samples of Synechococcus spp. occurred only during the day. A $200 \mathrm{ml}$ sample was preserved immediately with $5 \%$ buffered formalin stored on ice and kept in the dark. Upon return to the laboratory, samples were refrigerated at $5{ }^{\circ} \mathrm{C}$ until they were filtered and enumerated for FDC and cell abundance, as described previously (Campbell \& Carpenter 1986).

Calculations of growth rate were made using the equation of McDuff \& Chisholm (1982):

$$
u=\frac{1}{n \cdot t_{d}} \sum_{i=1}^{j=n} \ln \left(1+f_{1}\right)
$$

where $\mu=$ specific growth rate $\left(\mathrm{d}^{-1}\right) ; f_{1}=$ fraction of dividing cells for one sampling interval; $n=$ number of sampling intervals; $t_{d}$ is the duration of division. We assumed a $t_{d}$ of $3 \mathrm{~h}$ (Campbell \& Carpenter 1986). Specific growth rate is divided by $\ln 2$ to obtain divisions $\mathrm{d}^{-1}$.

The rate of production (PP) of the Synechococcus spp. population in the Sound was calculated from the growth rate, $\mu\left(\mathrm{d}^{-2}\right)$, the population density at the start of the day, $N_{0}$, and an average carbon content $1 \mathrm{C}$ cell $\left.{ }^{-1}\right)$ :

$$
\mathrm{PP}=\mu N_{\mathrm{o}} \mathrm{C} \mathrm{cell}^{-1}\left(\mu \mathrm{g} \mathrm{C} \mathrm{l^{-1 }} \mathrm{d}^{-1}\right)
$$

We used a carbon value of $105 \mathrm{fg} \mathrm{C}$ cell-1, which is based on recent laboratory experiments with oceanic clones ( $\mathrm{H}$. Glover pers. comm.).

The rate of daily production within the euphotic zone ( $\mathrm{mg} \mathrm{C} \mathrm{m} \mathrm{m}^{-2} \mathrm{~d}^{-1}$ ) was calculated assuming a yearly mean euphotic zone depth of $10 \mathrm{~m}$. In Long Island Sound the euphotic zone extends to between 10 and $15 \mathrm{~m}$ depth during the summer and ca $2.5 \mathrm{~m}$ in the winter (Conover 1956).

\section{RESULTS}

A pronounced diel cycle of cell division for Synechococcus spp. populations was observed for most of the year. The frequency of dividing cells (FDC) generally exhibited a daytime maximum which occurred during midday. For example, on 5 July 1984 there was a maximum of $26 \%$ cells dividing at 11:00 h, followed by a sharp decline (Fig. 2). A similar, though less pronounced, FDC pattern was observed from August through November. In June and July of the following year, the percentage of dividing cells again was a relatively large fraction of the population (Fig. 2). During these months the percentage of dividing cells during the night was low $(<5 \%)$. As daylength became shorter, the peak in FDC gradually decreased, and in February 1985 the maximum FDC shifted to later in the day (Table 1).

In August 1984, weekly samples were collected to observe variability on a shorter time scale. The magnitude of the percentage of dividing cells decreased progressively through the month (Fig. 3).

Synechococcus spp. cell concentration reached a peak of $232 \times 10^{6}$ cells $1^{-1}$ in August, coincident with the water temperature maximum (Fig. 4). Abundance subsequently declined through the autumn, and by January we found only $3 \times 10^{6}$ cells $1^{-1}$. Fewer than $10^{6}$ cells $1^{-1}$ were observed until the end of May. By July, the concentration rose to $9.9 \times 10^{6}$ cells $^{-1}$, a value close to that observed during the previous July. Insolation, as recorded at Brookhaven National Laboratory, $28 \mathrm{~km} \mathrm{SE}$ of Crane Neck, was greatest in mid-August at 512 ly $\mathrm{d}^{-1}$ and dropped to the lowest values of 142 and 146 ly $\mathrm{d}^{-1}$ on December and January sample dates, respectively.

The estimated growth rate remained at $>0.5$ divisions $\mathrm{d}^{-1}$ from July to October (Fig. 4). Except in December, growth rate declined throughout the winter months, and no growth could be measured in March through May. At the end of May, growth rate was highest $\left(1.56 \mathrm{div} . \mathrm{d}^{-1}\right)$, and remained above $0.6 \mathrm{div} . \mathrm{d}^{-1}$ in July (Fig. 4)

The samples collected during the winter months, 
Fig. 2. Synechococcus spp. Diel patterns of percentage of dividing cells
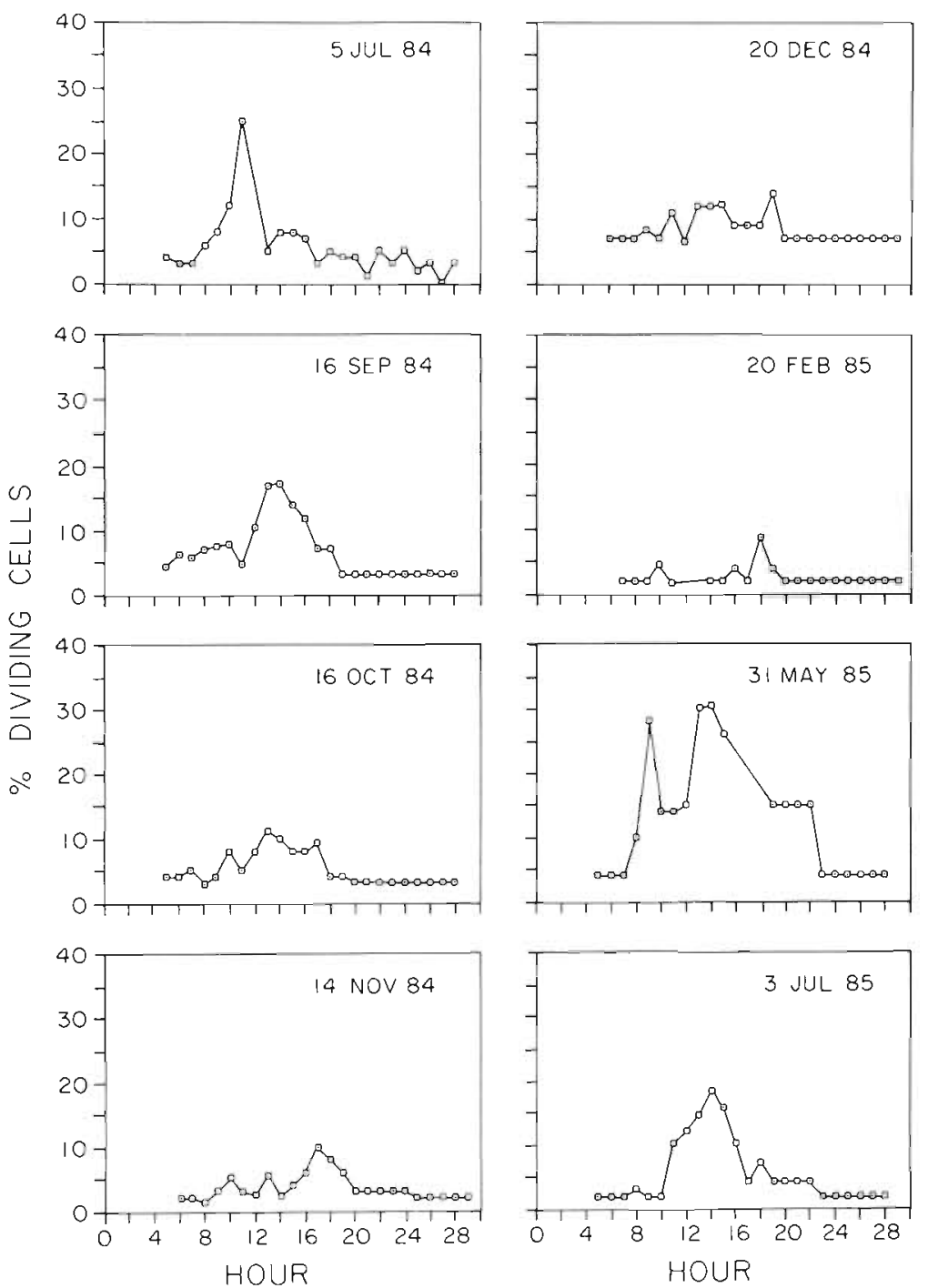

Table 1. Synechococcus spp. cell density, calculated rate of production (assuming average euphotic zone of $10 \mathrm{~m}$ depth), daily maximum percent dividing cells, and time of observed maximum in cell division. FDC: frequency of dividing cells

\begin{tabular}{|c|c|c|c|c|c|}
\hline Date & $\begin{array}{c}\text { Cells } \\
\left(10^{6} 1^{-1}\right)\end{array}$ & $\begin{array}{c}\text { Temperature } \\
\left({ }^{\circ} \mathrm{C}\right)\end{array}$ & $\begin{array}{c}\text { Production } \\
\left(\mathrm{mgC} \mathrm{m}^{-2} \mathrm{~d}^{-1}\right)\end{array}$ & $\begin{array}{l}\text { Maximum } \% \\
\text { FDC }\end{array}$ & $\begin{array}{l}\text { Time of } \\
\text { maximum (h) }\end{array}$ \\
\hline 5 Jul 1984 & 27 & 18.0 & 35 & 25.4 & $11: 00$ \\
\hline 2 Aug 1984 & 168 & 23.2 & 60 & 17.3 & $12: 00$ \\
\hline 9 Aug 1984 & 232 & 24.3 & 115 & 14.4 & $12: 00$ \\
\hline 16 Aug 1984 & 89 & 24.8 & 30 & 10.2 & $13: 00$ \\
\hline 29 Aug 1984 & 92 & 22.0 & 33 & 10.4 & $13: 00$ \\
\hline 18 Sep 1984 & 31 & 20.8 & 16 & 17.2 & $15: 00$ \\
\hline 16 Oct 1984 & 14 & 17.5 & 5 & 10.3 & $13: 00$ \\
\hline 14 Nov 1984 & 14 & 10.6 & 4 & 10.3 & $17: 00$ \\
\hline 20 Dec 1984 & 15 & 7.5 & 10 & 12.2 & none \\
\hline 23 Jan 1985 & 3 & -0.5 & 1 & 11.5 & none \\
\hline 20 Feb 1985 & 0.7 & 3.8 & 0.1 & 8.6 & $18: 00$ \\
\hline $20 \mathrm{Mar} 1985$ & 0.1 & 7.1 & 0 & none & none \\
\hline 23 Apr 1985 & 0.03 & 11.5 & 0 & none & none \\
\hline 6 May 1985 & 0 & 11.5 & 0 & none & none \\
\hline 31 May 1985 & 0.3 & 15.7 & 0.3 & 32.0 & $14: 00$ \\
\hline 3 Jul 1985 & 9.9 & 19.7 & 4 & 18.3 & $14: 00$ \\
\hline
\end{tabular}




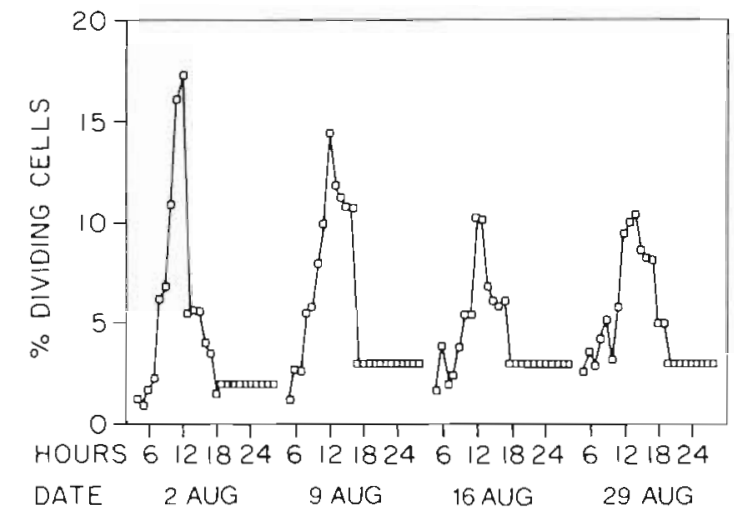

Fig. 3. Synechococcus spp. Weekly samples of percentage of dividing cells during August 1984

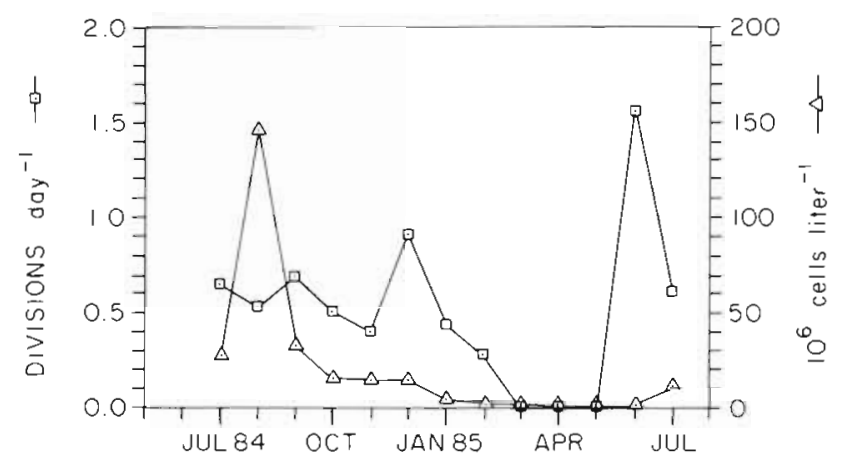

Fig. 4. Synechococcus spp. abundance and estimated growth rates (divisons $\mathrm{d}^{-1}$ ) between July 1984 and July 1985

December and January, did not exhibit the typical pattern of cell division. A distinct peak was not observed, and the FDC did not fall below $5 \%$ during night-time. If cells were completing division, a decreased percentage should have been observed at night (Fig. 2). The relatively constant percentage is indicative of a non-viable (non-growing) population (Waterbury et al. 1986). Growth rate estimates for these months, 0.91 and 0.44 div. $\mathrm{d}^{-1}$, were not consistent with cell concentration and ambient conditions (i.e. 0 to $2{ }^{\circ} \mathrm{C}$ ).

\section{DISCUSSION}

Natural populations of Synechococcus spp. in Long Island Sound exhibited an afternoon maximum in the percentage of dividing cells throughout most of the year. This pattern is similar to the diel cycles observed for laboratory cultures of the strain WH 7803, but is quite different from the observations of Sargasso Sea populations. In general, for WH 7803 the time of the maximum FDC was between 12:00 and 16:00 h (Campbell \& Carpenter 1986), whereas the Sargasso Sea surface populations displayed peaks in cell division at sunset and sometimes at night (Campbell \& Carpenter 1986, Prezelin et al. 1987).

The magnitude of the peak in cell division has been used as a relative indication of growth rate (Waterbury et al. 1986). Daily variation of percent dividing cells for the Woods Hole Synechococcus spp. population during September 1981 exhibited peaks ranging from 12 to $30 \%$. This variation was attributed to fluctuations in cloud cover and daily total solar radiation. Our weekly samplings in August 1984 also showed variability, with maxima ranging from 10 to $17 \%$, but with a progressive decrease over the month (Fig. 3). Throughout the year, the maxima followed the trend of cell abundance (Table 1). Growth rates calculated from the FDC data obviously were also related to the peaks in dividing cells. Estimated growth rates ranged from 0.5 to 0.7 div. $\mathrm{d}^{-1}$ for July through October, when cells were fairly abundant (Fig. 4). The highest growth rate (1.56 div. $\mathrm{d}^{-1}$ ) was observed at the end of May, which most likely was when the population was in its exponential growth phase. Seasonal pattern of abundance in Long Island Sound is similar to what is observed in the Woods Hole region, Massachusetts (Waterbury et al. 1986).

During the winter, when water temperature fell below $10^{\circ} \mathrm{C}$, the diel pattern in FDC was not at all pronounced. Because the population did not exhibit a definite peak in division, and the FDC remained fairly constant and elevated, we suspected that the population was not actively growing. In such a case, the assumptions of the FDC method are not met, i.e. (1) all cells are not actively growing, and (2) cells may not be completing division. Thus, the growth rates calculated for December through February must be interpreted with caution. The growth rate for December is most likely an overestimate, unless perhaps a different strain (a cold water clone) became dominant. Using immunofluorescence assays, we found the WH 7803 serogroup to be more prevalent in summer (15 to $50 \%$ ) than during winter $(<12 \%$ ) (Campbell \& Carpenter 1987).

Grazing on Synechococcus spp. may be an important factor in the seasonal pattern of abundance. Unfortunately, no information is available on seasonal changes in rates of grazing by microheterotrophs on Synechococcus. Synechococcus populations in Long Island Sound are characterized by a high $\left(0.5\right.$ to 0.7 div. $\left.\mathrm{d}^{-1}\right)$ growth rate in early July through October. The population reached its annual peak in August. If the population of microheterotrophs increases during this time, then the dramatic decrease in cell density in September to October, in spite of the continued relatively high growth rates, could be explained. By February, the Synechococcus abundance decreased to below $10^{6}$ cells $l^{-1}$, at which time no dividing cells were observed. It is possible that heterotrophic protozoan grazing 
might also affect our estimates of Synechococcus growth rates. If dividing cells are preferentially grazed (because they are larger), then our observed percentages of FDC would be underestimates. Consequently, FDC-based division rates would be underestimated. This might explain the decreasing growth rates observed from September through November; however, temperature also decreased during this period.

There was no clear relationship between growth rate of Synechococcus spp. and temperature. Regressions did not yield statistically significant lines, possibly because strains or serogroups changed in abundance in proceeding through the seasons thus resulting in cells which were adapted to the changed conditions.

The calculated (using Eq. 2) rates of primary production by Synechococcus spp. revealed that the greatest production occurred in August when the average daily rate was $6 \mathrm{mg} \mathrm{C} \mathrm{m}^{-3} \mathrm{~d}^{-1}$. Since the specific growth rate remained high through the autumn, a significant, yet reduced rate of production occurred during this period, in spite of the marked decrease in cell density.

Synechococcus spp. appear to contribute little to water column primary productivity in Long Island Sound. Annual rate of primary production by Synechococcus was $4 \mathrm{~g} \mathrm{C} \mathrm{m}^{-2} \mathrm{yr}^{-1}$. There are no recent estimates of the annual rate of primary production for Long Island Sound; however, a value of ca $250 \mathrm{mg} \mathrm{C}$ $\mathrm{m}^{-2}$ is typical of such water. For example, Smayda (1957) calculates an annual rate of primary production of $220 \mathrm{~g} \mathrm{C} \mathrm{m}^{-2}$ for nearby Narragansett Bay, Rhode Island. If we assume a rate of $250 \mathrm{mg} \mathrm{C} \mathrm{m}^{-2} \mathrm{yr}^{-1}$ for Long Island Sound, then on an annual basis Synechococcus contribute only ca $2 \%$ of the total primary production. It has been shown on numerous occasions that picoplankton are extremely important primary producers in oceanic environments (Glover 1985). Their contribution to production in coastal regions, however, is a much lower percentage than that in open ocean waters. Using FDC-based growth rates, our estimate of the contribution by Synechococcus spp. to the total production in Long Island Sound is less than the previous estimate of $6 \%$ for a Northwest Atlantic coastal station (Glover et al. 1986).

Acknowledgements. This research was supported by NSF grants OCE8515730, OCE8710798 and OCE8214764. We thank the following for sitting on the beach and collecting samples: Ohad Jehassi, Scott Petrish, Sherry Login, Jeng Chang and Susan Dunham.

\section{LITERATURE CITED}

Bienfang, P. K., Takahashi, M. (1983). Ultraplankton growth rates in a subtropical ecosystem. Mar. Biol. 76: 213-218

Campbell, L., Carpenter, E. J. (1986). Diel patterns of cell division in marine Synechococcus spp. (Cyanobacteria): the use of the frequency of dividing cells technique to measure growth rate. Mar. Ecol. Prog. Ser. 32: 139-148

Campbell, L., Carpenter, E. J., Iacono, V. J. (1983). Identification and enumeration of marine chroococcoid cyanobacteria by immunofluorescence. Appl. environ. Microbiol. 46: $553-559$

Campbell, L., Carpenter, E. J. (1987). Characterization of Phycoerythrin containing Synechococcus spp. populations: seasonal and geographic distribution patterns. J. Plankt. Res. 9: 1167-1181

Conover, S. A. M. (1956). Oceanography of Long Island Sound, 1952-1954. IV. Phytoplankton. Bull. Bingham oceanogr. Collect. XV: 62-112

Cuhel, R. L., Waterbury, J. B. (1984). Biochemical composition and short-term nutrient incorporation patterns in a unicellular marine cyanobacterium, Synechococcus (WH7803). Limnol. Oceanogr. 29: 370-374

Glover, H. E., Campbell, L., Prézelin, B. B. (1986). Contribution of Synechococcus spp. to size fractioned primary productivity in three water masses in the Northwest Atlantic. Mar. Biol. 91: 193-203

Li, W. K. W., Subba-Rao, D. V., Harrison, W. G., Smith, J. C., Cullen, J. J., Irwin, B., Platt, T. (1983). Autotrophic picoplankton in the tropical ocean. Science 219: 292-295

McDuff, R. E., Chisholm, S. W. (1982). The calculation of in situ growth rates of phytoplankton from populations of cells undergoing mitosis: a clarification. Limnol. Oceanogr. 27: 783-788

Murphy, L. S., Haugen, E. (1985). The distribution and abundance of phototrophic ultraplankton in the North Atlantic. Limnol. Oceanogr. 30: 47-58

Platt, T., Subba-Rao, Irwin, B. (1983). Photosynthesis of picoplankton in the oligotrophic ocean. Nature, Lond. 301: $702-704$

Prézelin, B. B., Glover, H. E., Campbell, L. (1987). The effects of light intensity and nutrient availability on diel patterns of cell metabolism and growth in populations of Synechococcus spp. Mar. Biol. 95: 469-480

Smayda, T. J. (1957). Phytoplankton studies in lower Narragansett Bay. Limnol. Oceanogr. 2: 342-359

Waterbury, J. B., Watson, S. W., Valois, F. W., Franks, D. G. (1986). Biological and ecological characterization of the marine unicellular cyanobacterium Synechococcus. In: Platt, T., Li, W. K. W. (eds.) Photosynthetic picoplankton. Can. Bull. Fish. Aquat. Sci. 214: 71-120 